\title{
Article \\ Planning Tool Mosaic (PTM): A Platform for Italy, a Country Without a Strategic Framework
}

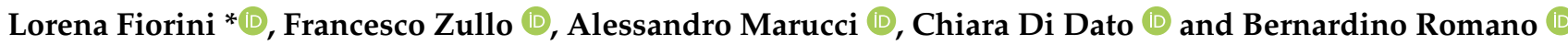 \\ Department of Civil, Construction-Architectural and Environmental Engineering, University of L'Aquila, \\ 67100 L'Aquila, Italy; francesco.zullo@univaq.it (F.Z.); alessandro.marucci@univaq.it (A.M.); \\ chiara.didato@graduate.univaq.it (C.D.D.); bernardino.romano@univaq.it (B.R.) \\ * Correspondence: lorena.fiorini@univaq.it
}

check for updates

Citation: Fiorini, L.; Zullo, F.; Marucci, A.; Di Dato, C.; Romano, B. Planning Tool Mosaic (PTM): A Platform for Italy, a Country Without a Strategic Framework. Land 2021, 10, 279. https://doi.org/10.3390/ land 10030279

Academic Editor: Fabrizio Battisti

Received: 27 January 2021

Accepted: 4 March 2021

Published: 8 March 2021

Publisher's Note: MDPI stays neutral with regard to jurisdictional claims in published maps and institutional affiliations.

Copyright: (c) 2021 by the authors. Licensee MDPI, Basel, Switzerland. This article is an open access article distributed under the terms and conditions of the Creative Commons Attribution (CC BY) license (https:// creativecommons.org/licenses/by/ $4.0 /)$.

\begin{abstract}
The following work proposes the utilisation of a technical device named "Planning Tool Mosaic" (PTM), defined as a total homogeneous and standardised framework for the principles contained in municipal regulatory plans: the assignment of zoning, legends, and technical rules. The $300,000 \mathrm{~km}^{2}$-broad national territory is divided into nearly 8000 municipalities. Each of them refers to a distinct regulatory plan and then to a distinct regulation on local buildings, infrastructure, and social services. This level of planning tool is the one that has most impact on the territory. This highly fragmented scenario should be driven by upper-level regulation. Although protocols and guidelines are in force, they are almost irrelevant compared to the impact of regulation at the local level. This process is a European example of city planning mismanagement that needs to be brought to the broader attention of the European technical/scientific context. The PTM, though intervening when municipal plans are already in effect, introduces an element of social and political transparency to planning before transformative events occur. It also provides a continuous framework on the probable future of territories, thereby overcoming the current opacity with regard to public cognition of future arrangements.
\end{abstract}

Keywords: planning tool; molecular planning; planning strategy

\section{Introduction}

This work proposes the utilisation of a technical device named "Planning Tool Mosaic" (PTM), defined as a homogeneous and standardised framework of the principles contained in municipal regulatory plans (PRG) in force in a given territorial region: the assignment of zoning, legends, and technical norms that define city planning tasks.

Only very few Italian regions already have a PTM, but these are purely informative layers and do not comply with general rules and shared at the national level. In the following, these examples will be used to clarify the contents that should be required for a standardised device. This device should be included institutionally in the Italian planning framework in order to overcome some pathologies in territorial control that characterise it in comparison to other Western European countries. Most of these countries use "hierarchical" planning systems that operate on various spatial/administrative levels, such that the more local plans must transpose the instructions of those operating at higher levels. Italy also has national and many regional regulations that specify this procedure, but, unlike France, Germany, and Great Britain [1-4], the highest levels of planning have never had a decisive role in conditioning decisions made at the lowest level. Indeed, to clarify the need for the PTM, it is necessary to start from the description of the near-total autonomy of the Italian municipalities in managing transformations of all kinds, practically without any higher-level strategic control. This condition has gradually worsened, with a generalised indifference over several decades. Only recently have the pathological sides been perceived: an unjustified over-urbanisation in a very inorganic configuration, which is extremely energy-consuming and much in conflict with the public interest in environmental 
and urban quality $[5,6]$. The loss of quality caused by the lack of control over the action of municipal plans is seriously reflected on the landscape structures as a whole and on the physiognomy of the structures built. Those mentioned are perhaps the most visible aspects from external observers that also cause significant economic losses and interest from tourist flows $[7,8]$. This phenomenon has greatly increased the contradiction between high urban growth and the abandonment of existing places. In fact, in Italy there is a huge amount of unused and/or abandoned building capital. This issue is encountered at various scales from the single abandoned buildings (private or public) to small urban spaces, entire urban areas, and whole municipalities (i.e., municipalities of Italian inner areas). For this reason, it is necessary to introduce useful support decisions tools that will allow us to have a broader territorial vision, especially in the current historical period in which land planning and territorial policies are moving towards the application of urban regeneration programs and the reuse of empty spaces [9-14]. In a territorial planning system nearly devoid of a strategy that drives municipalities toward spatial and dimensional organisational goals for urban functions and with an eye to the large scale, the only applicable possibility in Italy today is the careful, continuous mosaicing of local city planning tools, at least at the regional level. This is a form of ex post facto control, which is ineffective since it acts after municipal plans are already in effect. However, mosaicing introduces an element of social and political transparency for planning before transformative events occur, which has high utility both for the social collective and for regional agencies. The PTM provides a framework that continues into the probable future of the territories, overcoming the current opacity and leading to public awareness of future arrangements, such that they may intervene with possible conscious, participatory, and monitoring actions. In the current situation, it is essentially impossible to understand what is going to happen geographically in territory outside of the individual municipality and, in particular, to evaluate ex ante the land consumption or environmental damage that will occur in the time horizon of action of the municipal plans.

It is, after all, a rather well-known fact that, although Italian historic centres maintain high landscape and architectural quality, which is recognised and appreciated throughout the world, the urban textures created in the last 50 years probably have distributive, constructive, and formal characteristics that are on average among the worst, at least in Europe. It is certainly true that the Italian urban planning law of 1942 (Law no. 1150 of 17 August 1942) was one of the first and most innovative of its kind, introducing planning at various levels and city planning extended to the entire municipal territory, limiting construction activity for municipalities without urban planning tools, but it is also true that many of these valuable contents, including the right of public expropriation in expansion zones, were either never implemented or used methods that lost regulatory energy over the course of time [15]. After 1942, Italy no longer issued national laws on urban planning or the transformation of land, and all legislative activity on the topic was delegated, starting from the 1970s, to the country's 20 regions. Although very intense over time, this activity was characterised by a strong dishomogeneity and, again, by a weak capacity for strategic regulation, progressively lightening the forms of control and increasingly allocating decision-making roles to individual municipalities, no matter how small and demographically irrelevant [16-19].

In reality, eminent and widely admired academics had given some indication of the inefficiency of Italian planning starting in the 1980s. Unfortunately, the near-totality of the literature produced was in Italian, and therefore the bibliography dutifully included many titles which are very difficult to access [20-22].

The parts that follow show some examples of results of the extreme autonomy in the decision-making of the Italian municipalities. This paper will present the PTM tool in its essential characteristics, highlighting the technical problems and organisational protocol, using some pilot experiences already present in some regions who have produced spontaneously their own PTM outside of any national standard. Finally, we delineate the 
technical modalities to transform the PTM into an institutional tool for regions that are part of the procedural framework of the territorial government.

\section{Materials and Methods}

The research conducted used some databases about PTMs, demographic data, and urbanisation data (Table 1).

Table 1. Databases used for the analysis.

\begin{tabular}{|c|c|c|}
\hline Data & Source & Website \\
\hline $\begin{array}{l}\text { the demographic data, and any information } \\
\text { regarding urbanisation }\end{array}$ & ISTAT database & $\begin{array}{c}\text { http: / / www4.istat.it/it/archivio/209722 } \\
\text { (accessed on 25 January 2021), } \\
\text { http:/ / demo.istat.it/ (accessed on 25 January } \\
\text { 2021). }\end{array}$ \\
\hline $\begin{array}{c}\text { recent dynamic }(2012,2015,2016) \text { of } \\
\text { urbanisation }\end{array}$ & ISPRA database & $\begin{array}{l}\text { http:/ / www.sinanet.isprambiente.it/it/sia- } \\
\text { ispra/download-mais / consumo-di-suolo/ } \\
\text { carta-nazionale-consumo-suolo/cartografia_ } \\
\text { consumo_suolo_10m-1/view (accessed on } \\
\text { 25 January 2021) }\end{array}$ \\
\hline Other territorial and environmental data & DUSAF database & $\begin{array}{l}\text { http:/ / www.cartografia.regione.lombardia.it/ } \\
\text { metadata/Dusaf (accessed on } 25 \text { January 2021) }\end{array}$ \\
\hline PTM of Piedmont & Piedmont & $\begin{array}{l}\text { https: / / www.geoportale.piemonte.it/cms / } \\
\text { (accessed on } 25 \text { January 2021) }\end{array}$ \\
\hline PTM of Lombardy & Lombardy & $\begin{array}{l}\text { http:/ / www.geoportale.regione.lombardia.it/ } \\
\text { (accessed on } 25 \text { January 2021) }\end{array}$ \\
\hline PTM of the Metropolitan Area of Bologna & The Metropolitan Area of Bologna & $\begin{array}{c}\text { https:/ / dati.emilia-romagna.it/dataset/ } \\
\text { mosaico-prg--eb6e2588 (accessed on } \\
\text { 25 January 2021) }\end{array}$ \\
\hline PTM of the Province of Pesaro-Urbino & The Province of Pesaro-Urbino & $\begin{array}{c}\text { http://www.provincia.pu.it/funzioni/ } \\
\text { pianificazione-territoriale/altre-competenze/ } \\
\text { sistema-informativo-urbanistico-territoriale } \\
\text { (accessed on } 25 \text { January 2021) }\end{array}$ \\
\hline PTM of Umbria & $\begin{array}{c}\text { Elaboration of the authors developed within } \\
\text { the SUNLIFE project (LIFE } \\
13 / \text { NAT } / \text { IT } / 000371 \text { ) }\end{array}$ & $\begin{array}{c}\text { http:/ / www.life-sun.eu/ (accessed on } \\
\text { 25 January 2021) }\end{array}$ \\
\hline PTM of the Metropolitan Area of Naples & The Metropolitan Area of Naples & $\begin{array}{c}\text { https:/ / sciamlab.com/opendatahub / } \\
\text { dataset/r_campan_mosaico-p-r-g-p-u-c-psai- } \\
\text { adb-campania-centrale (accessed on } \\
\text { 25 January 2021) }\end{array}$ \\
\hline PTM of the Metropolitan Area of Rome & The Metropolitan Area of Rome & $\begin{array}{l}\text { http:/ / websit.cittametropolitanaroma.it/ } \\
\text { PRG.aspx (accessed on } 25 \text { January 2021) }\end{array}$ \\
\hline
\end{tabular}

In particular, the databases extractable from the individual PTMs are freely available online for Italy, as shown in Figure 1 (Piedmont, Lombardy, the Metropolitan Area of Bologna, the Province of Pesaro-Urbino, Umbria, the Metropolitan Area of Naples, the Metropolitan Area of Rome). Other PTMs have also been created, such as those of the Valle d'Aosta region and the Venice Metropolitan Area, but the data were not available or viewable on the web; however, it must be taken into account that the PTM is not a mandatory tool under Italian law, even on the regional level. 


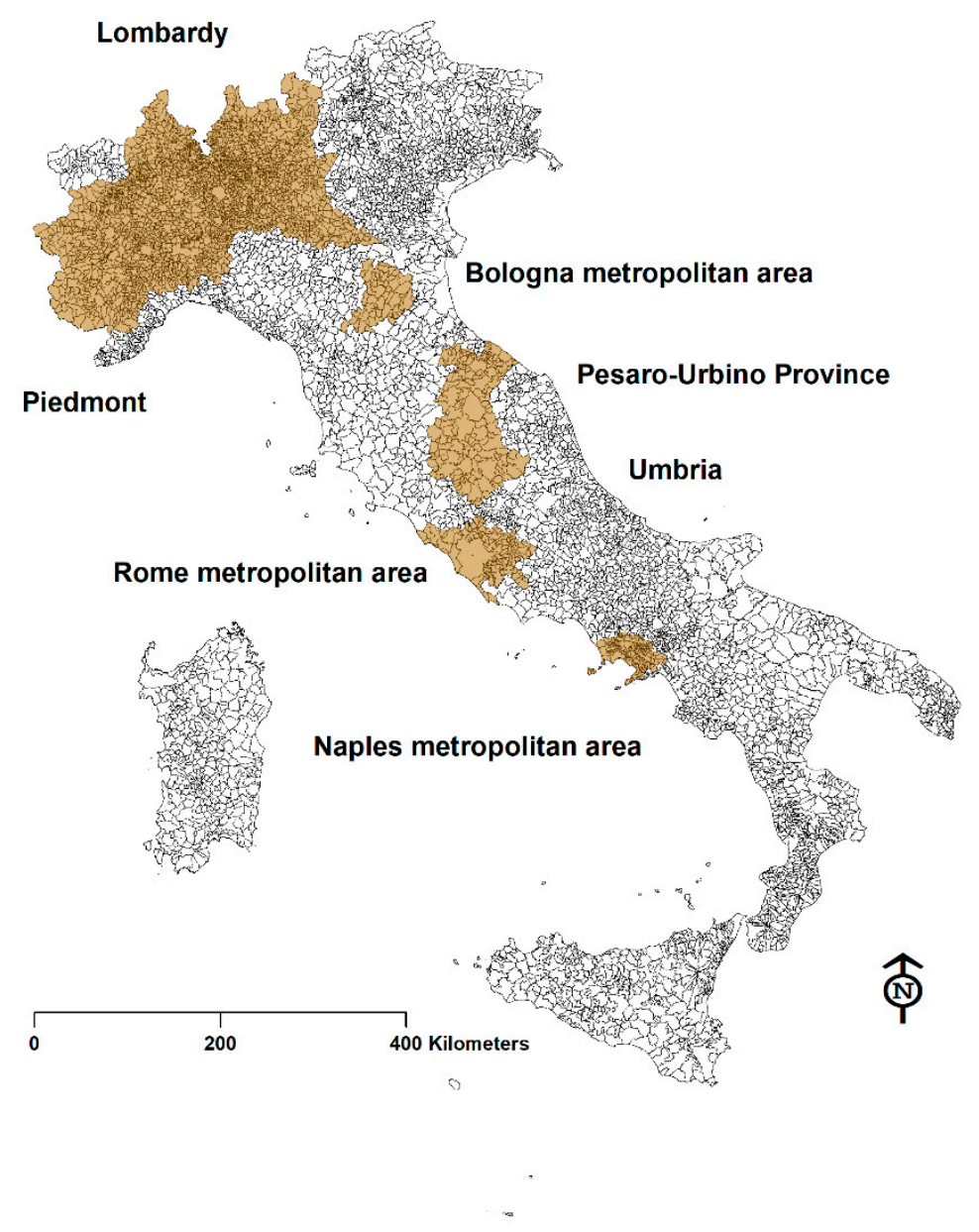

Figure 1. Italian administrative areas where a Planning Tool Mosaic (PTM) developed with an approved methodology is available on the web.

The Italian municipalities, demographic data, and any information regarding urbanisation were extracted from the ISTAT database with the territorial and administrative variations of municipalities, metropolitan cities, provinces, and regions and were updated and published on 6 April 2018 (http:/ / www4.istat.it/it/archivio/209722, http:/ /demo.istat.it/ (accessed on 25 January 2021)).

Other data on the recent dynamic $(2012,2015,2016)$ of urbanisation were extracted from the ISPRA (Istituto Superiore per la Protezione e la Ricerca Ambientale (Higher Institute for Environmental Protection and Research)) geoportal: http://www.sinanet. isprambiente.it/it/sia-ispra/download-mais/consumo-di-suolo/carta-nazionale-consumosuolo/cartografia_consumo_suolo_10m-1/view (accessed on 25 January 2021).

Other territorial and environmental data were gathered from the Information System of the Lombardy Region DUSAF (Destinazione d'Uso del Suolo Agricolo e Forestale (Land and Forest Use Database)) (http:/ / www.cartografia.regione.lombardia.it/metadata/Dusaf (accessed on 25 January 2021)) and from the Land Use papers available on the geoportals of the Italian regions.

The classification of the areas used by the Italian planning tools refers to the Interministerial Decree of 2 April 1968, n. 1444. This is a rule of the Italian Republic that introduce the limits and rules in urban planning, valid throughout the national territory and implemented by the General Regulatory Plans of each Italian municipality. The decree has defined the Italian urban planning standards. The best-known standards are related to the definition of homogeneous territorial zones and to the height and distance limits between buildings. The ministerial decree has undoubtedly influenced the urban development of Italian municipalities. 
Municipal activity is expressed, with the aforesaid prerogative of complete sovereignty, on extremely restricted parcels of territory ( $36 \mathrm{~km}^{2}$ on average), which only in recent years have reduced mildly in number, moving from over 8100 to the current 7955 . A total of 4370 of these municipalities-well over half the total-have a surface area of less than $25 \mathrm{~km}^{2}$ (corresponding to a $5 \times 5 \mathrm{~km}^{2}$ ), but 1667, a fifth of the national municipalities, have a surface area of less than $10 \mathrm{~km}^{2}\left(3 \times 3 \mathrm{~km}\right.$ long), with 165 having less than $3 \mathrm{~km}^{2}$ $(1.7 \times 1.7 \mathrm{~km})$ - that is, they are smaller than Central Park in New York. There are also some formidable peaks in municipalities with surface areas close to and less than $1 \mathrm{~km}^{2}$, up to the incredible 12 ha of Atrani (practically a "square" of $346 \times 346 \mathrm{~m}$, less than one third of the size of Tiananmen Square in Beijing and little more than St. Peter's Square in Rome), complete with a Regulatory Plan in progress. This method of planning, called "molecular planning", has been practiced for half a century and can no longer be considered suitable to resolve the current serious pathologies that were caused by it. In Figure 2, each point corresponds to a municipal planning tool which, aside from the rest, is also developed with chronological deadlines that are completely free and deregulated and that autonomously distribute the localisation and sizing of urban functions of every kind, regardless of their distribution in adjacent municipalities. It emerges rather clearly how irrational and substantially antithetical it is with the very concept of "planning", which, by its nature, should physiologically develop strategically and not in a hyperlocalised fashion.

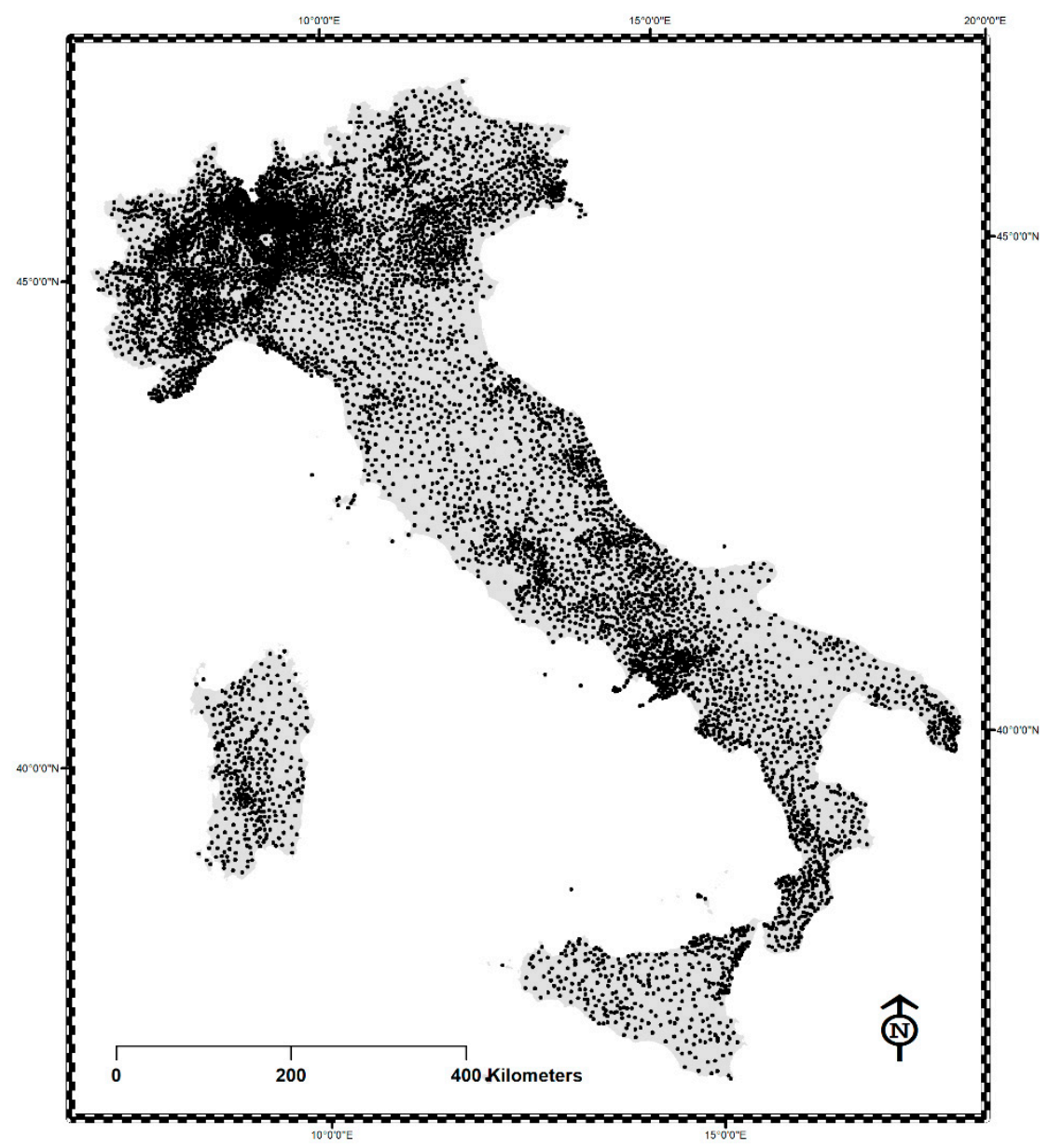

Figure 2. The centroids of the Italian municipalities. Each point corresponds to a different municipal planning tool.

In general, municipal plans always abound, correctly, with demographic projections in support of hypothetical new and extended residential and production areas, both when the population or the economic sectors register an increasing trend, but also when such projections are objectively contradicted by a long developmental series of negative indica- 
tors. For this reason, a comparison analysis was carried out on demographic dynamics, urban dynamics, and potential urban dynamics (extracted from the available PTMs). In fact, for the formulation of the PTM, this analysis was fundamental in highlighting the incongruity between urban growth and the actual need for settlement, caused above all by the low control of urban policies in the management of urban transformations. Figure 3 shows the applied methodology.

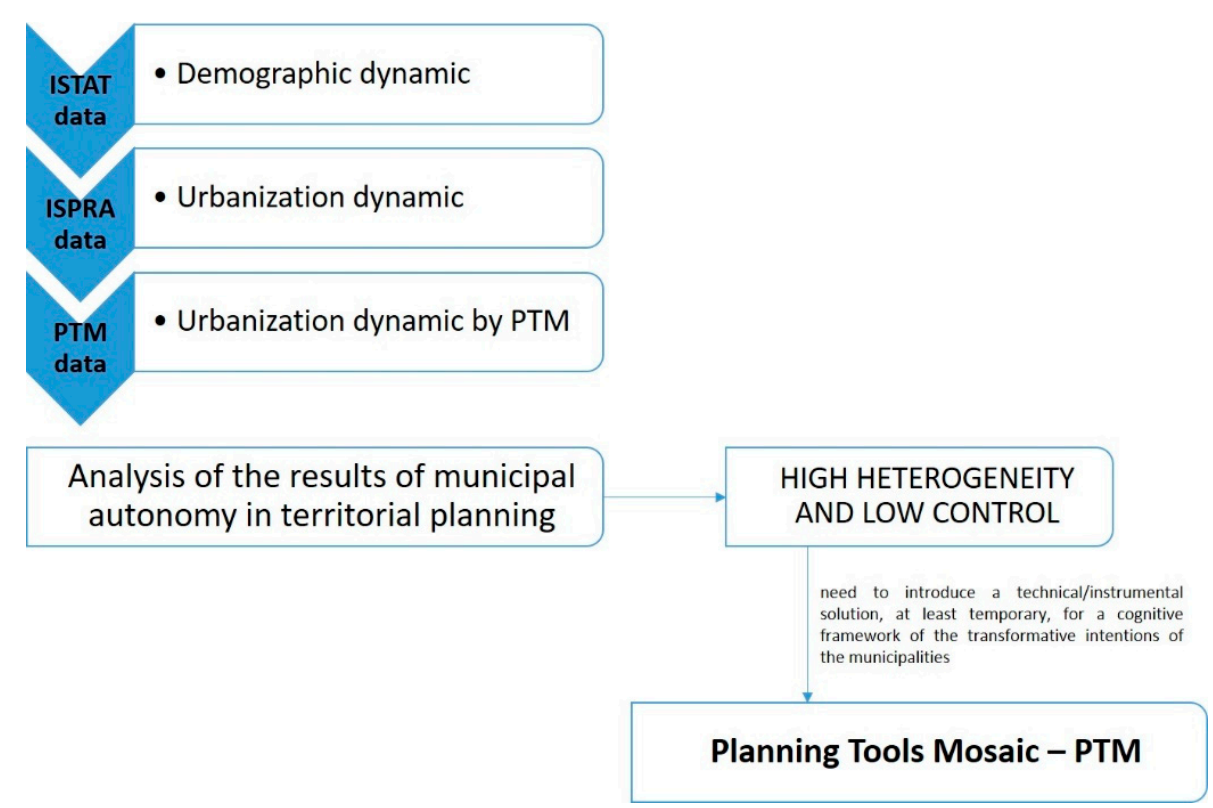

Figure 3. Flow chart of the applied methodology.

\section{Results}

Due to the unavailability of data for the whole national territory, the research was conducted only on the territories that have PTMs freely available online (Figure 1), as better specified in the previous paragraph. The results reported below concern four sample cases: Piedmont, Lombardy, Umbria, and the Metropolitan City of Naples. They were chosen because they are representative of the different Italian territorial areas. In fact, these regions are sample cases for northern, central, and southern Italy. Furthermore, these territories are also characterised by very heterogeneous demographic, urban, and socio-economic dynamics. The analysis carried out has highlighted the independence between demographic changes and urban growth repeatedly noted, but this phenomenon is difficult to attribute to specific causes.

Certainly important roles have covered some policies of the recent past that have financed the construction program of productive buildings (industrial, commercial, artisanal, directional) in an excessive number compared to the real economic demand, as well as the change in the family structure.

This statement can be verified using the sample of the Umbria Region, for which an accurate and updated PTM is available [23]. The 92 municipal plans of the region, more than half of which were updated after 2010 and another 23 after 2005, with very few exceptions, predicted an increase in the current urbanised surface area from 50 to $150 \%$, with some municipalities pushing to exceed even $200-250 \%$ (Figure 4 ). These are extremely high rates, as they both include municipalities with a serious demographic increase over the last twenty years (but which exceed $20 \%$ in one case only), but also a very large number of municipalities with very contained or stable increases $(<5 \%)$, or even with strong decreases, including ones near to or greater than $10 \%$. Essentially, there is no correlation between historic series of demographic dynamics and developmental population scenarios which each individual municipality may propose in justification of the provision of residential or productive spaces. In the Umbrian case, which currently shows a per capita urbanisation 
of approximately $350 \mathrm{~m}^{2} /$ inhabitant, the increase in urbanisation itself predicted by the plans ( $84 \%$ more) would correspond to almost double the current 884,000 inhabitants over a time horizon of 10 to 20 years: a hypothesis of $3.5 \%$ per year is completely unreasonable, considering the demographic trend of the last fifty years with an average rate of $2 \%$.

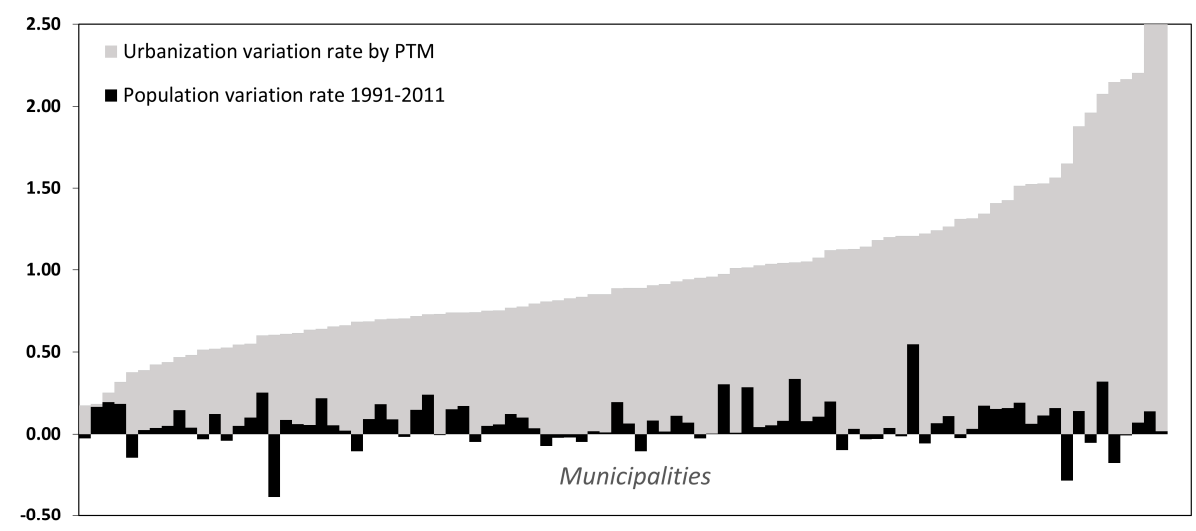

Figure 4. Demographic dynamics for the period 1991-2011 compared to the rate of urban increase per individual municipality according to their planning tools inserted in the Umbria region PTM.

The situation described for Umbria refers to a sample of municipalities of an urban density (UD) varying from $3 \%$ to a maximum of less than $10 \%$ (average regional UD $=5 \%$ ), but some findings are quite different coming from investigations in the municipalities of Lombardy, the Italian region, along with Veneto, with the highest average rate of UD (approximately 14\%). The more than 1500 Lombardy municipalities, with the lowest average size in Italy $\left(15.74 \mathrm{~km}^{2}\right)$, boast very high levels of urbanisation of up to $94 \%$, with nearly 500 having above $25 \%$ (one quarter) of their territory covered by settlements. The theoretical scenario of the plans implemented would see the urban density of Lombardy rise from 14 to $16 \%$, with an increase in the urbanised surface area of more than $500 \mathrm{~km}^{2}$, which represents $15 \%$ more than the current urban extension extracted from the DUSAF (just over $3300 \mathrm{~km}^{2}$ ).

Considering only the municipalities with a UD less than $25 \%$, a different situation can be observed from that of Umbria in absolute values. The diagrams in Figure 5 show a very strong concentration of samples in the expansion range foreseen from 0 to $10 \%$ for current urbanisation.

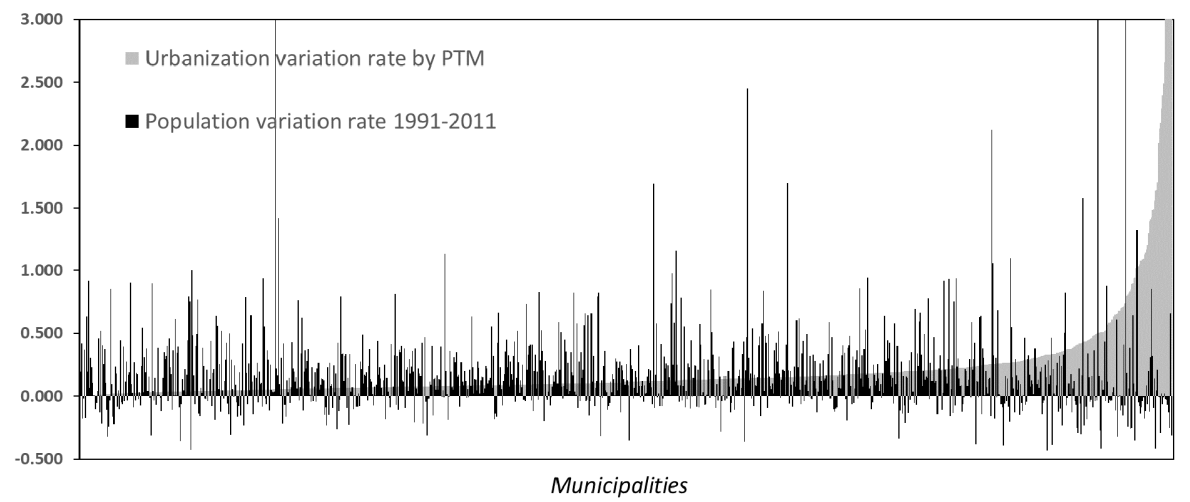

Figure 5. Demographic dynamics for the period 1991-2011 compared to the rate of urban increase per individual municipality according to their planning tools inserted in the Lombardy region PTM. Municipalities with Urban Density (UD) $<25 \%$.

In any case, the expansive forecasts of the Lombardy PTM, compared at $341 \mathrm{~m}^{2} /$ per capita of urban surface area, prefigure a population increase for the next 10-20 years of 1,500,000 inhabitants, or 15\% more. Considering that from 1991 to 2011 the population 
increased by $9.6 \%$ for Lombardy as well, the values in play are rather oversized, although with a delta much less than that of Umbria. Instead, municipalities with a UD $>50 \%$ (Figure 6) have plans with very limited expansive content due to the saturation of their territorial spaces.

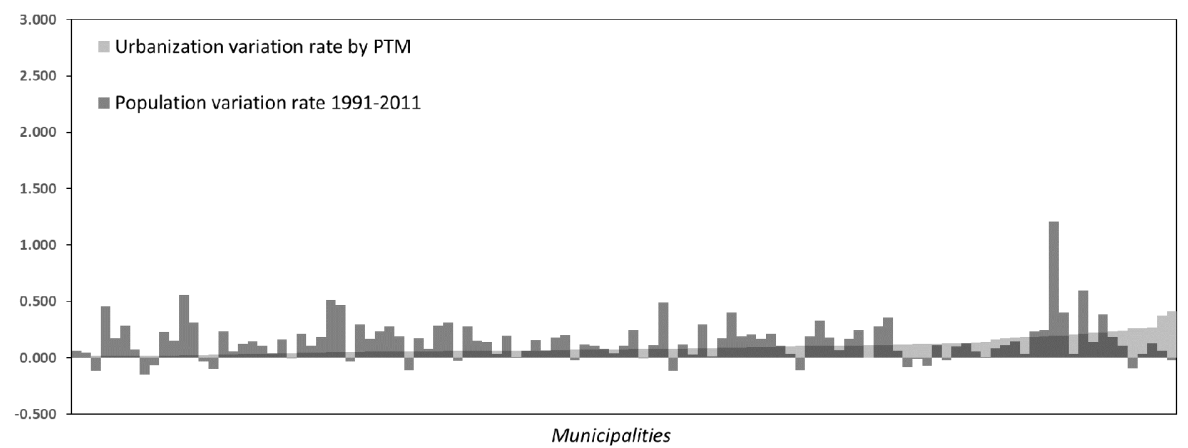

Figure 6. Demographic dynamics for the period 1991-2011 compared to the rate of urban increase per individual municipality according to their planning tools inserted in the Lombardy region PTM. (Municipalities with Urban Density (UD) $>50 \%$ ).

Piedmont is in a dimensionally intermediate situation (Figure 7). If all the contents of the municipal plans were implemented, the regional urban density would rise from 7 to $10 \%$, with an added surface area of nearly $900 \mathrm{~km}^{2}$ corresponding to approximately $50 \%$ of the current level reported by ISTAT $\left(1714.59 \mathrm{~km}^{2}\right)$. With a current urban surface area per capita of $390 \mathrm{~m}^{2}$ /inhabitant, the prospective trend of the region contained in the forecasts of the municipal plans would correspond to approximately 2.5 million more inhabitants in the time horizon of $10-20$ years, or more than $50 \%$ of the inhabitants of 2011. Considering that from 1991 to 2011 the population increased by 1\% for Piedmont, the municipal demographic aspirations are well beyond any reasonable projection.

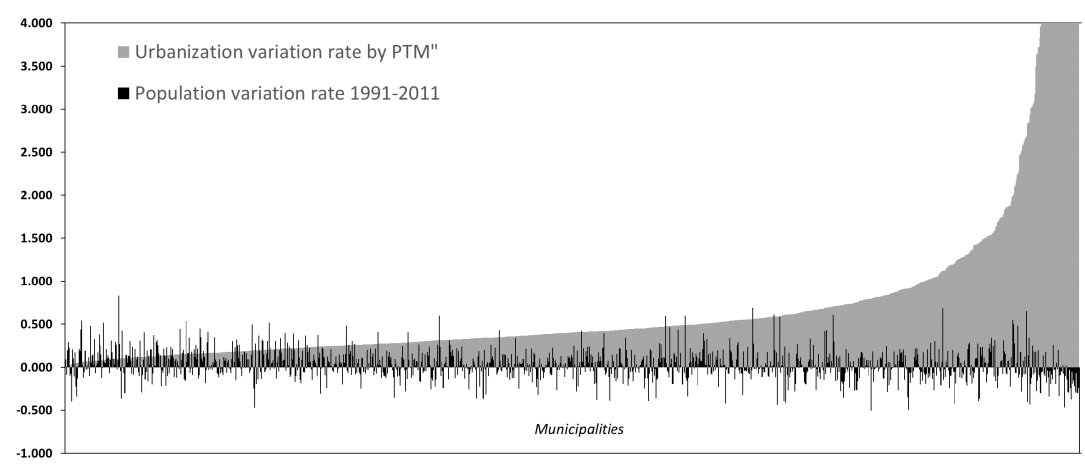

Figure 7. Demographic dynamics for the period 1991-2011 compared to the rate of urban increase per individual municipality according to the Piedmont region PTM.

Moving to the metropolitan area of Naples, which also has the PTM, the current urban density for the area under study $\left(1810 \mathrm{~km}^{2}\right.$ equal to $14 \%$, approximately the entire region of Campania) is $36 \%$. With the implementation of the PTM, this would move to $43 \%\left(+119 \mathrm{~km}^{2}\right.$, equal to $18 \%$ of the amount currently urbanised-that is, $\left.659.04 \mathrm{~km}^{2}\right)$. The current per capita urbanisation reaches $183 \mathrm{~m}^{2} /$ inhabitant (half of what was found for other Italian regions, but this is an area with a habitation density equal to approximately $2000 \mathrm{inhab} / \mathrm{km}^{2}, 10$ times the national value). Maintaining the same standard, $119 \mathrm{~km}$ of urban surface area forecast would correspond to 650,000 new inhabitants; in the last 20 years (1991-2011), the population increased by approximately 80,000 units-that is, $2.3 \%$ over those resident in 1991. The number of additional inhabitants predicted by the plan is equal to $18 \%$ of those found in 2011: even if the population is increasing, since the data for 2017 show 136,800 more inhabitants than there were in 2011, approximately $4 \%$ of the data 
from the first time section, the increase of $18 \%$ is in any case enormously greater than the dynamics measured.

For all four regions analysed, the samples confirm a substantial indifference from each municipality to the positive or negative demographic balance, and this is valid for both the entire set of municipalities analysed (Figure 8) and their dimensional clusters. In all cases, furthermore, no significant distributions for sub-environments of value or geographics were found. For the Lombardy plans, however, a certain tendency to limit urban expansion can be gathered, probably due to the elevated saturation of the region in this sense and also due to the fact that the PRGs are nearly all very recent [18] — that is, created after 2010, when the national debate on land use started to spread.
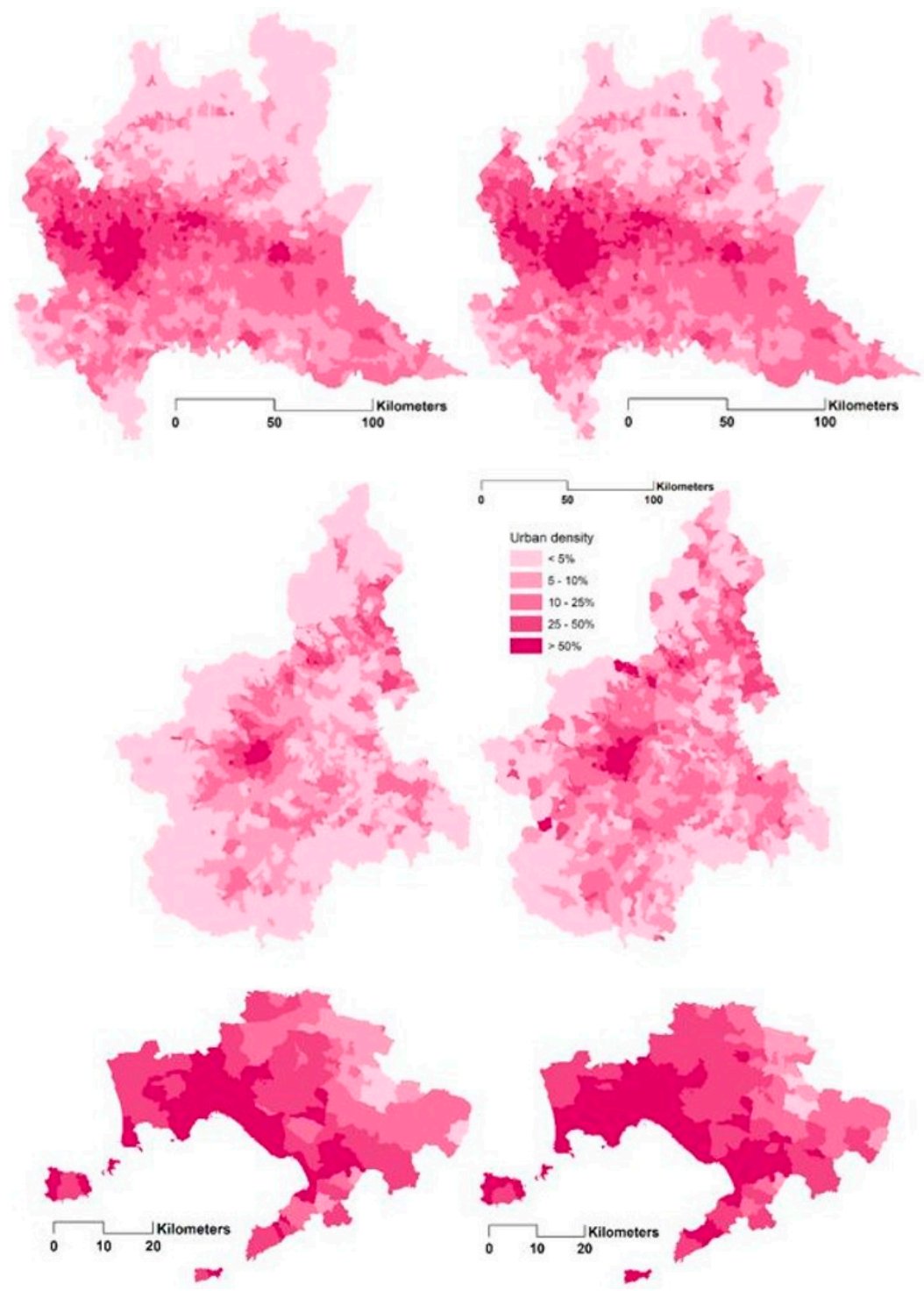

Figure 8. Variations in urbanisation density deriving from the complete implementation of the contents of the municipal regulatory plans in three sample cases (from high to low) of Lombardy, Piedmont, and the Metropolitan City of Naples.

These assessments reveal the need to have available at least an overall framework (PTM) for current municipal planning to be able to trace a reliable profile of the potential future arrangement of the territory. 


\section{Discussion}

As can be deduced as far, creating the PTM is an onerous operation for regions, both for the initial system and especially for maintenance and updating over time. If there are no rules for the technical development of municipal plans, the task of mosaicing is very onerous and costly and requires copious resources, including specialised staff and office equipment. Considering that in a region with hundreds of municipalities the updating of plans is a rather frequent activity, the inclusion of new documents and the updating of the database requires a daily effort from various staff units. This is also made necessary by the fact, cited above, that the production of the plans is not done by feasible and unified time deadlines, but is completely free and therefore the new tools become effective at random intervals. It is just for this reason that the near totality of the Italian regions, if we exclude those used as a sample in this work, do not have PTMs in an efficient and official versionthat is, to be considered an institutional layer of the agency available on geoportals. It is rather astounding, moreover, that PTMs are not made available publicly by regions that are notoriously very efficient in territorial planning, such as Trentino Alto-Adige or Emilia Romagna. For the rapid formation of the PTM, it would require the production of municipal plans that follow a uniform standard, and some example of regulation in this sense actually exists. Perhaps the most rigorous in Italy is that of the Sicily region. This region has made available the "Technical Directives for the computerisation of the General Regulatory Plans: codification of graphics and standard legend" with Circular no. 02/2017, Department of Urban Planning, on technical directives (http:/ / www.sitr.regione.sicilia.it/?page_id=1139 (accessed on 25 January 2021)). In this document, the region indicates the standardisation procedures of the General Regulatory Plans through a series of steps:

- The coding of the graphics and symbolisms to be used to identify the homogeneous zones, the restricted areas, and the land use destinations through the creation of a standard legend;

- Defining technical and informatics characteristics of the documentation through the organisation and naming of the folders and files;

- Defining characteristics of the basic cartography formats to be used for the works.

This is an important experience that should be taken up by all the Italian regions in order to end up, in many years' time, with a national database, unimaginable today, capable of providing extraordinary information. The INU Report from the Territory [24], confirms these statements showing a net "peninsula effect". In general, northern regions have more updated plans than south-central ones, which have been in force for more than thirty years with completely anachronistic and unreliable contents [25-27].

\section{Technical Characteristics of the PTM}

As already anticipated in the introduction, a PTM contains the summary of the contents of individual municipal planning tools, using a unified legend obtained from the interpretation of the zone assignments indicated in the source documents. In this way, the zoning of $n$ plans that flow together into PTMs are welded into a single layer accompanied by a single database. Of course, it would also be possible to prepare a simply spatial PTM, maintaining the original synoptic items of the individual plans, but this would compromise the searchability of the device relative to the macroscopic effect deriving from the summary of the indications of the individual municipalities. As a consequence, the PTM generally follows the technical procedure shown in Figure 9. 


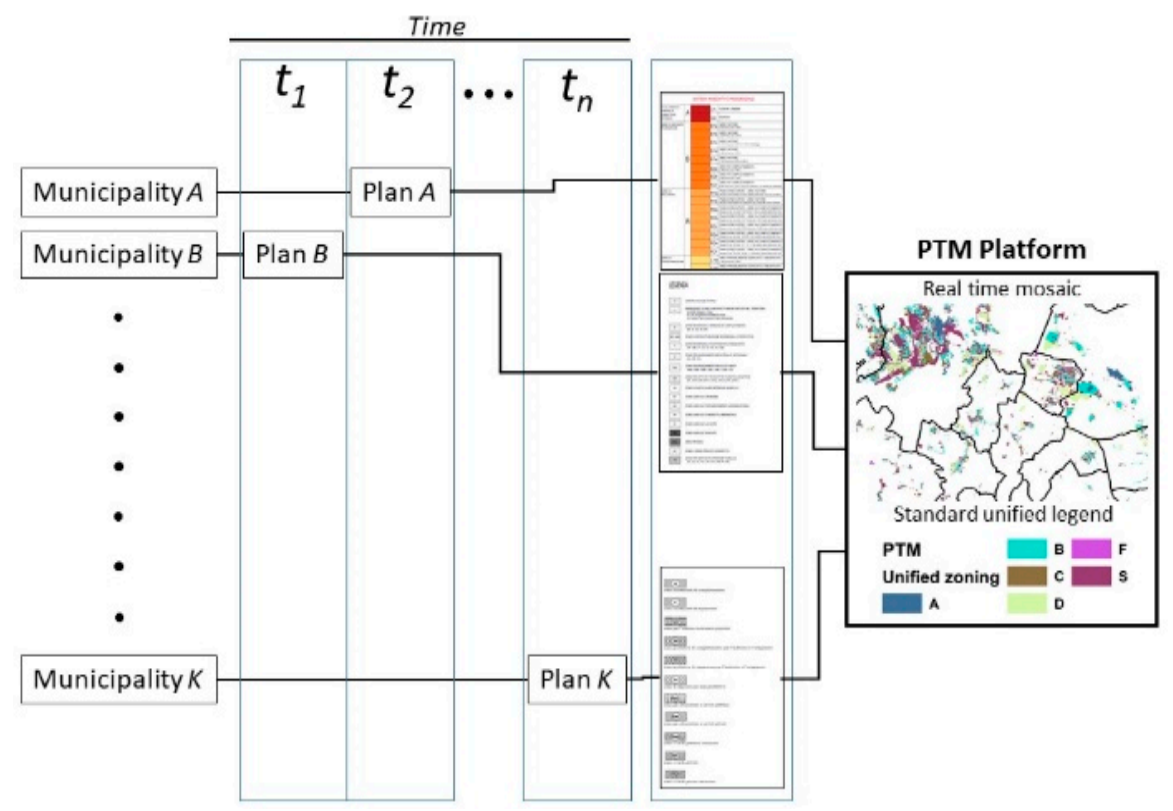

Figure 9. PTM technical procedure platform. In this figure, the field of the "custom legend" shows only the symbolic configurations of the typical legends of Italian plans.

It presents a series of non-banal technical problems tied to the preparation of the standard, unified legend due to the difficulty of homologating the various use assignments with respect to the national definitions (homogeneous zones Ministerial Decree 1444/68). Figures 10-12 show the results in the case of the Umbria region, with detail on each individual municipality, the unified legend, and the regional framework obtained. Both the regulatory plans of the municipalities, and as a consequence the PTMs when existent, do not follow rules for the standardisation of symbols and definitions. Therefore, it is currently extremely complex, both to construct the mosaics and then to compare them among various administrative territories [28,29].

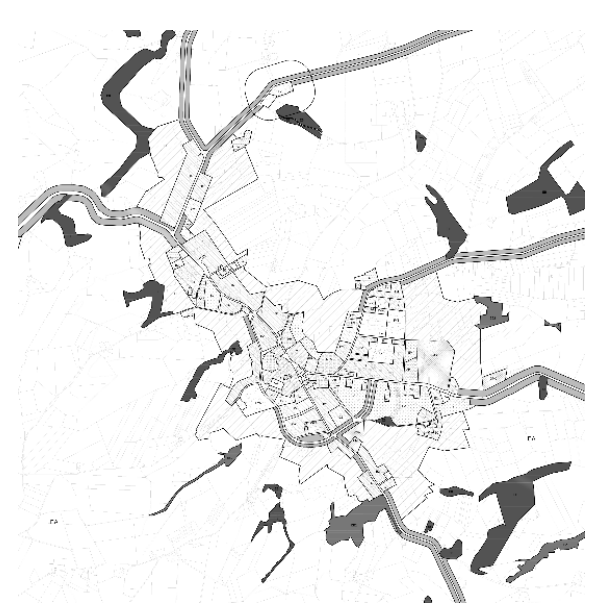

(a)

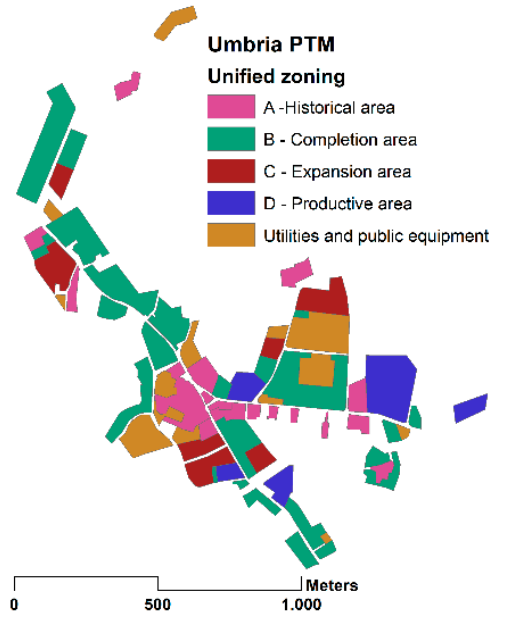

(b)

Figure 10. Example of development of conversion from the original configuration (a) of the plan to the version of settlement contents with a unified legend for regional PTM (b). 


\section{LEGENDA}

\begin{tabular}{|c|c|}
\hline A & CENIRI E NUCLEI STORICI \\
\hline A & 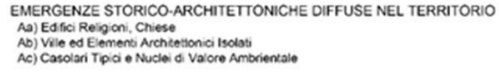 \\
\hline B & $\begin{array}{l}\text { ZONE RESIDENZIAL AMMESSE DI COMPLETAMENTO } \\
(\mathrm{BO}, \mathrm{B1}, \mathrm{B2}, \mathrm{B3}, \mathrm{B4})\end{array}$ \\
\hline BR DMR & ZONE DI RISTRUTTURAZIONE RESIDENZIALI O PRODUTTIVE \\
\hline c & $\begin{array}{l}\text { ZONE RESIDENZIALIDI ESPANSIONI CONDIZIONATE } \\
(C O, C O P, C 1, C 2, C 3, C 4, C A, C X P)\end{array}$ \\
\hline D & $\begin{array}{l}\text { ZONE PER INSEOIAMENTI INDUSTRIALI E ARTIGIANALI } \\
\text { (DA, DB, DC) }\end{array}$ \\
\hline DM & $\begin{array}{l}\text { ZONE PER INSEDIAMENTI PRODUTTMM MISTI } \\
\text { (DMA, DMB, DMB', DMC, DMC1, DMS, DS) }\end{array}$ \\
\hline DT & $\begin{array}{l}\text { AREE PER ATTIVTA' PRODUTTIVE TURISTICO-RICETTIVE } \\
\text { (DT, DTA, DTB, DTC1, DTC2, DTC3, DTK, DTK1) }\end{array}$ \\
\hline EA & ZONE DI PARTICOLARE INTERESSE AGRICOLO \\
\hline EC & ZONE AGRICOLE ORDINARIE \\
\hline ED & ZONE AGRICOLE PER INSEDIAMENTI AGROINDUSTRIALI \\
\hline EF & ZONE AGRICOLE DI RISPETTO URBANISTICO \\
\hline EL & ZONE AGRICOLE LACUSTRI \\
\hline EB & ZONE AGRICOLE BOSCATE \\
\hline EB2 & AREE RIPARIALI \\
\hline EV & ZONE A VERDE PRNAATO DI RISPETTO \\
\hline FA & $\begin{array}{l}\text { ZONE PER SERVIZI DI INTERESSE PUBBUCCO } \\
\text { (FA FD, FG, FG', FH, FH1, FM, FP, FR) }\end{array}$ \\
\hline FI & $\begin{array}{l}\text { ZONE PER SERVZZI E ATTREZZATURE PUBBLICHE } \\
\text { (Fio, Fis, FPC, FT, FZ) }\end{array}$ \\
\hline $\mathrm{FF}$ & ZONE PER ATTREZZATURE PER ATTIVITA' MLLITARI \\
\hline FS & ZONAFERROVIARIA \\
\hline $\mathrm{FV}$ & $\begin{array}{l}\text { ZONE PER VERDE PUBBLLCO E ATIREZZATURE SPORTIVE } \\
\text { (FVA, FVA1, FVA1", FVA2, FVA3, FVS, FVS1) }\end{array}$ \\
\hline
\end{tabular}

\begin{tabular}{l|c|}
\hline ENGLISH LEGEND & UNIFIED SYNTHETIC LEGEND \\
HISTORICAL CENTERS & \\
HISTORICAL AND & A- HISTORICAL ZONES \\
\hline ARCHITECTURAL ELEMENTS & \\
DISPERSED IN THE TERRITORY & \\
\hline ZONES OF RESIDENTIAL & \\
COMPLETION & \\
\hline RESIDENTIAL OR & \\
MANUFACTURING & B - COMPLETION ZONES \\
\hline RESTRUCTURING AREAS & \\
\hline EXPANSION RESIDENTIAL & C- RESIDENZIAL EXPANSION \\
\hline ZONES & ZONES \\
\hline AREAS FOR INDUSTRIAL OR & \\
\hline ARTISAN SETTLEMENTS & \\
\hline ZONES FOR MIXED & \\
MANUFACTURING & \\
INSTALLATIONS & D- PRODUCTIVE EXPANSION \\
\hline AREAS FOR TOURIST- & ZONES \\
\hline RECEPTIVE ACTIVITIES & \\
\hline AREAS OF PARTICULAR & \\
\hline AGRICULTURAL INTEREST & \\
\hline NORMAL AGRICULTURAL \\
ZONES
\end{tabular}

Figure 11. An example from a municipal regulatory plan from 2011—from the original legend (in Italian language) to the unified legend for PTM (Ref. Ministerial Decree 1444/68).

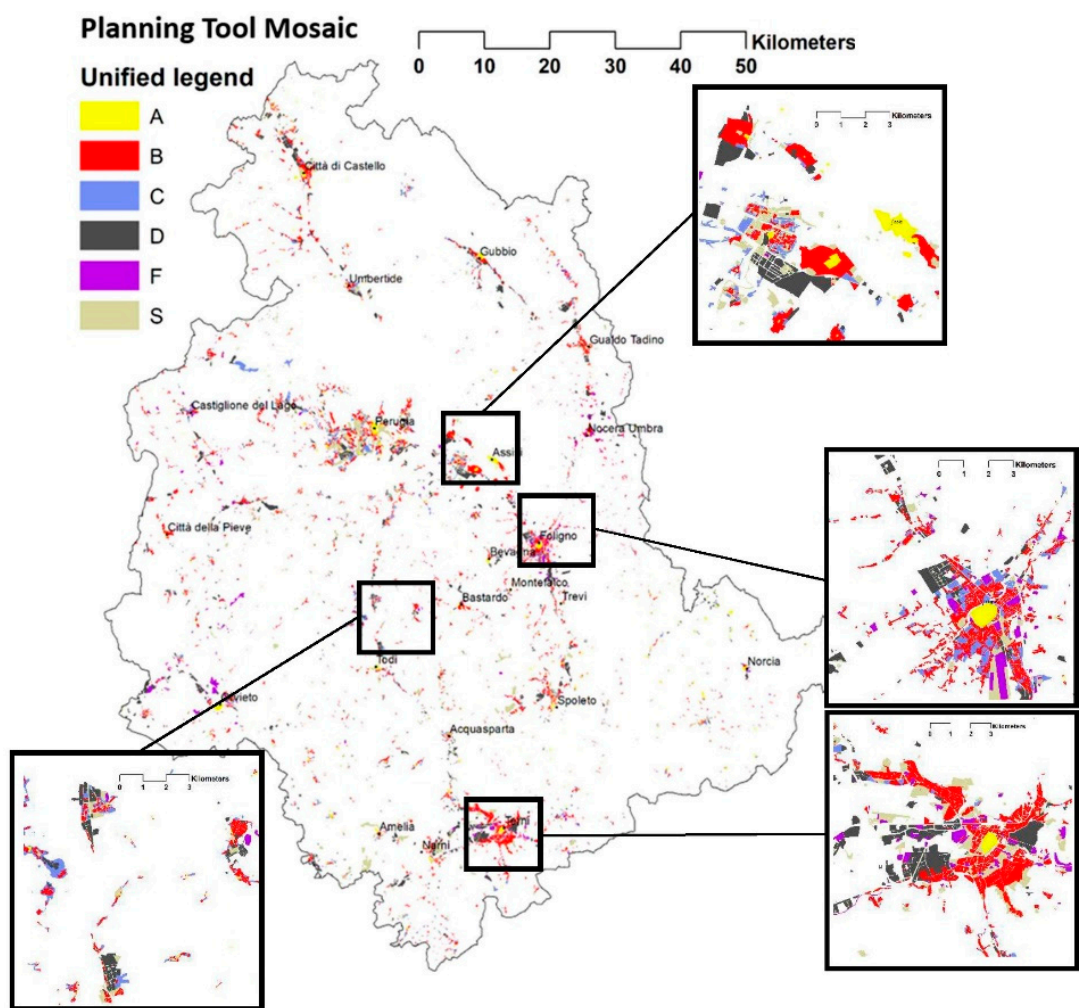

Figure 12. PTM of the Umbria region with unified legend (Ref. Ministerial Decree 1444/68). 
For this reason, the products available today are complex to interpret and in general they are created only to externally translate the configuration of the municipality plan, but not as containers for data and information useful to better strategically govern the territory. The amount of data that can be extracted from a PTM is large, deriving from the recomposition of all the current municipal plans, and the most important indicators are the zoning (Figure 13), the urbanised surface area expected, the per capita presence of urbanised areas and services, and the virtual settable inhabitants. An important aspect that should not be forgotten is the contribution that the PTM could provide to computing illegal construction at a regional scale, a crime which is assessable exclusively on the municipal level, comparing the building situation in the territory with the governance introduced by regulatory plans. This is a notorious pathological phenomenon in Italy, particularly in some geographic areas (in the metropolitan area of Naples alone, $72 \mathrm{~km}^{2}$ of illegal construction surface have been estimated), but which presents enormous difficulties in recording and fighting precisely due to the lack of technical tools allowing spatial selection with a low tolerance of uncertainty.

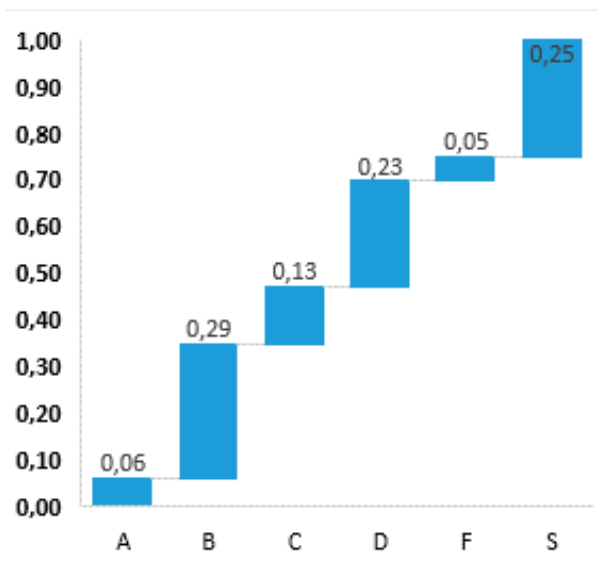

Figure 13. Makeup of the PRG zones extracted from the PTM of the Umbria region.

Currently, we are working on the draft of the PTM guidelines within the project called "Sost.EN.\&Re-Sostenibilità, resilienza, adattamento per la tutela degli ecosistemi e la ricostruzione fisica in Italia Centrale", supported by Ministry for Environment, Land, and Sea Protection of Italy and in collaboration with the Abruzzo Region. The specific aim is to implement a set of tools that are useful for regional planning (Abruzzo Region). A wider aim is to propose tools that may be valid also for other regions.

\section{Conclusions}

To deal with these issues, a deep city planning reform is necessary, like those adopted since the 1970s in France, Germany, and Great Britain [30-37]. These European countries removed some decision-making prerogatives from municipal autonomy on the sizing and localisation of residential, industrial, and service areas. They gave this role to the form of coordinated planning with more strategic visions, which are also set out in national and regional laws, but almost never applied. After all, the problem of the relationship between the contents of the plans and the real effects on the territory have also been dealt with in other experiences [38,39].

However, Italian political culture and sensibility do not currently allow putting into the pipeline norms and measures that could actually affect the current condition. For this reason, this work proposes a solution, at least temporary, of a technical/instrumental type (Planning Tools Mosaic-PTM), which could at least allow us to obtain a cognitive framework of the transformative intentions of the municipalities in order to carry out real monitoring actions and, possibly, control—although in a limited way-the prospects for territorial arrangement resulting from the uncoordinated summation of individual municipal activities. 
Recently, Parliament passed Law 158/2017, which provides financial support to small municipalities (less than 5000 inhabitants) for "the structural, economic, and social development of small municipalities through financing investments in the environment and cultural assets, the safeguarding and restoration of historic centres, the security of the street infrastructure and schools and the establishment of new manufacturing activities". It is extremely likely that this measure will be ineffective, given the limited resources made available ( $€ 30,000$ per municipality, spread out over four years). In this sense, a problemoriented regulation should be more efficient than simplistic formulas and general supports. A focused regulation may streamline the services and incentive innovative planning forms and tools as the PTM. These are also (perhaps) hetero-directed forms of planning (by the regions), as has been seen in numerous cases, in which municipal size does not actually allow a strategic vision of prospects, administering, and planning, which are therefore more on the wave of hopes and aspirations than the unequivocal sign of reality.

Of course, one could respond to these considerations by saying that designing expansion areas in PRGs does not mean that these actually develop, but that would be an implicit declaration of the uselessness of the plans as tools for controlling and directing territorial transformations. The only regret of the authors is that the debate on these topics in Italy is currently quite dormant and does not enjoy significant attention, either from scientific societies or the public administration, at any level. It follows that, at least in the meantime, things will continue to proceed as they have up to now, and so we felt that it was important to raise these issues in an article of international scope.

Author Contributions: Conceptualisation, L.F. and B.R.; methodology, L.F. and A.M.; software, F.Z.; validation, L.F., A.M., and C.D.D.; data curation, F.Z. and C.D.D.; writing-original draft preparation, L.F. and B.R.; writing-review and editing, L.F. and C.D.D.; supervision, B.R. All authors have read and agreed to the published version of the manuscript.

Funding: This research was funded by "Bando SNSvS2-Sost.EN.\&Re Sostenibilità, resilienza, adattamento per la tutela degli ecosistemi e la ricostruzione fisica in Italia Centrale".

Institutional Review Board Statement: Not applicable.

Informed Consent Statement: Not applicable.

Data Availability Statement: http:/ / www4.istat.it/it/archivio/209722 (accessed on 25 January 2021); http:/ / demo.istat.it/ (accessed on 25 January 2021); http:/ / www.sinanet.isprambiente.it/it/ sia-ispra/download-mais/consumo-di-suolo/carta-nazionale-consumo-suolo/cartografia_consumo_ suolo_10m-1/view (accessed on 25 January 2021); http:/ / www.cartografia.regione.lombardia.it/ metadata/Dusaf (accessed on 25 January 2021).

Acknowledgments: The methodology presented has been implemented both in the research project “Bando SNSvS2 - Sost.EN.\&Re Sostenibilità, resilienza, adattamento per la tutela degli ecosistemi e la ricostruzione fisica in Italia Centrale" supported by Ministry for Environment, Land and Sea Protection of Italy (Italian: Ministero dell'Ambiente e della Tutela del Territorio e del Mare, also known as MATTM), in collaboration with the Abruzzi region, and in other research project supported by the Umbria region, which we want to thank for the resources given. The indicators used were developed within the SUNLIFE project (LIFE 13/NAT/IT/000371-Strategy for the Natura 2000 Network of the Umbria Region), and we are continuing to develop the methodology presented in the project Sost.EN.\&Re.

Conflicts of Interest: The authors declare no conflict of interest.

\section{References}

1. Newman, P.; Thornley, A. Urban Planning in Europe: International Competition, National Systems, and Planning Projects; Routledge: Oxfordshire, UK, 1996; p. 277. ISBN 0-203-42794-7.

2. Healey, P.; Williams, R. European urban planning systems: Diversity and convergence. Urban Stud. 1993, 30, 701-720. [CrossRef]

3. Naess, P. Urban planning and sustainable development. Eur. Plan. Stud. 2001, 9, 503-524. [CrossRef]

4. Couch, C.; Sykes, O.; Börstinghaus, W. Thirty years of urban regeneration in Britain, Germany and France: The importance of context and path dependency. Prog. Plan. 2011, 75, 1-52. [CrossRef] 
5. Romano, B.; Zullo, F.; Fiorini, L.; Marucci, A.; Ciabò, S. Land transformation of Italy due to half a century of urbanisation. Land Use Policy 2017, 67, 387-400. [CrossRef]

6. Romano, B.; Zullo, F.; Fiorini, L.; Ciabò, S.; Marucci, A. Sprinkling: An Approach to Describe Urbanization Dynamics in Italy. Sustainability 2017, 9, 97. [CrossRef]

7. Burger, J. Landscapes, tourism, and conservation. Sci. Total Environ. 2000, 249, 39-49. [CrossRef]

8. Gkoltsiou, A.; Terkenli, T.S. An interdisciplinary analysis of tourist landscape structure. Tourismos 2012, 7, 145-164.

9. Haddaway, N.R.; Styles, D.; Pullin, A.S. Environmental impacts of farm land abandonment in high altitude/mountain regions: A systematic map of the evidence. Environ. Evid. 2013, 2, 1-7. [CrossRef]

10. Di Figlia, L. Turnaround: Abandoned villages, from discarded elements of modern Italian society to possible resources. J. Int. Plan. Stud. 2016, 21, 278-297. [CrossRef]

11. Marucci, A.; Fiorini, L.; Di Dato, C.; Zullo, F. Marginality Assessment: Computational Applications on Italian Municipalities. Sustainability 2020, 12, 3250. [CrossRef]

12. Romano, B.; Fiorini, L. Abbandoni costi pubblici dispersione. Alla ricerca di risposte migliori. Sentieri Urbani 2018, 26 , 66-73.

13. Morano, P.; Tajani, F.; Anelli, D. Urban planning decisions: An evaluation support model for natural soil surface saving policies and the enhancement of properties in disuse. Prop. Manag. 2020, 38, 699-723. [CrossRef]

14. Strollo, A.; Smiraglia, D.; Bruno, R.; Assennato, F.; Congedo, L.; De Fioravante, P.; Giuliani, C.; Marinosci, I.; Riitano, N.; Munafò, M. Land consumption in Italy. J. Maps 2020, 16, 113-123. [CrossRef]

15. Brenna, S. A cinquant'anni dalla mancata riforma Sullo: La strana disfatta dell'urbanistica pubblica. In Lo Scandalo Urbanistico 50 Anni Dopo, 1st ed.; Fischer, T.B., Battisti, F., Eds.; Franco Angeli Ed.: Milan, Italy, 2017; pp. 69-76. ISBN 9788891754998.

16. Ave, G. Urban Land and Property Markets in Italy; UCL Press: London, UK, 1996; p. 206. ISBN 9781857280531.

17. Sartorio, F.S. Strategic spatial planning: A historical review of approaches, its recent revival, and an overview of the state of the art in Italy. Plan. Rev. 2005, 41, 26-40. [CrossRef]

18. Gabellini, P. Profiles of Italian urban planning. Planum 2008, 17, 1-15.

19. Colavitti, A.M.; Usai, N.; Bonfiglioli, S. Urban Planning in Italy: The Future of Urban General Plan and Governance. Eur. Plan. Stud. 2012, 21, 167-186. [CrossRef]

20. Salzano, E. La Città Sostenibile; delle Autonomie Ed.: Rome, Italy, 1992; p. 445.

21. Gibelli, M.C.; Salzano, E. No Sprawl; Alinea Ed.: Florence, Italy, 2006; p. 250.

22. Indovina, F. Dalla Città Diffusa ALL'ARCIPELAGO Metropolitano; Franco Angeli Ed.: Milan, Italy, 2009; p. 298. ISBN 9788856811704.

23. Zullo, F. Un approccio critico alla pianificazione urbanistica comunale. Il caso della Regione Umbria. In Proceedings of the 21st ASITA National Conference, Salerno, Italy, 21-23 November 2017. ISBN: 978-88-941232-8-9.

24. INU. Rapporto dal Territorio 2016; INU: Rome, Italy, 2016; p. 263. ISBN 978-88-7603-153-3.

25. Dematteis, G. Il Fenomeno Urbano in Italia: Interpretazioni, Prospettive, Politiche; Franco Angeli Ed.: Milan, Italy, 1992; p. 256. ISBN 9788820469412.

26. ANCI-IFEL. 1861-2011, L'italia dei Comuni, 150 Anni di Unità; ANCI: Rome, Italy, 2011; p. 89.

27. Milani, G. I Comuni Italiani Secoli XII-XIV; Laterza: Bari, Italy, 2005; p. 200. ISBN 8842072478.

28. Sferlazza, E. Proposta di un modello vettoriale multitemporale per la rappresentazione e la gestione in ambiente GIS dei PRG comunali. In Proceedings of the 8th ASITA National Conference, Rome, Italy, 14-17 December 2004; pp. 1821-1826.

29. Zoppi, M. Per un mosaico ragionato dei piani strutturali. In Contesti: Città, Territori, Progetti; (1/2, 2009); rivista del Dipartimento di urbanistica e pianificazione del territorio, Università di Firenze: Florence, Italy, 2009; pp. 120-122.

30. John, P.; Cole, A. Urban regimes and local governance in Britain and France: Policy adaption and coordination in Leeds and Lille. Urban Aff. Rev. 1998, 33, 382-404. [CrossRef]

31. Wiegandt, C. Urban development in Germany: Perspectives for the future. Geo J. 2000, 50, 5-15.

32. Pauleit, S.; Duhme, F. Assessing the environmental performance of land cover types for urban planning. Landsc. Urban Plan. 2000, 52, 1-20. [CrossRef]

33. Weber, C. Interaction model application for urban planning. Landsc. Urban Plan. 2003, 63, 49-60. [CrossRef]

34. Cullingworth, J.B.; Nadin, V. Town and Country Planning in the UK; Routledge: Oxfordshire, UK, 2006; p. 573. ISBN 0-415-35809-4.

35. Schmidt, S.; Buehler, R. The Planning Process in the US and Germany: A Comparative Analysis. Int. Plan. Stud. 2007, 12, 55-75. [CrossRef]

36. Sager, T. Neo-liberal Urban Planning Policies: A Literature Survey, 1990-2010. Prog. Plan. 2011, 76, 199. [CrossRef]

37. Lord, A.; Tewdwr-Jones, M. Is planning "Under Attack"? Chronicling the deregulation of urban and environmental planning in England. Eur. Plan. Stud. 2014, 22, 345-361. [CrossRef]

38. Tiana, L.; Lib, Y.; Yanc, Y.; Wangc, B. Measuring urban sprawl and exploring the role planning plays: A Shanghai case study. Land Use Policy 2017, 67, 426-435. [CrossRef]

39. Abrantes, P.; Fontes, I.; Gomes, E.; Rocha, J. Compliance of land cover changes with municipal land use planning: Evidence from the Lisbon metropolitan region (1990-2007). Land Use Policy 2016, 51, 120-134. [CrossRef] 